This article was downloaded by: [University of Montana]

On: 09 April 2015, At: 15:05

Publisher: Taylor \& Francis

Informa Ltd Registered in England and Wales Registered Number: 1072954 Registered office:

Mortimer House, 37-41 Mortimer Street, London W1T 3J H, UK

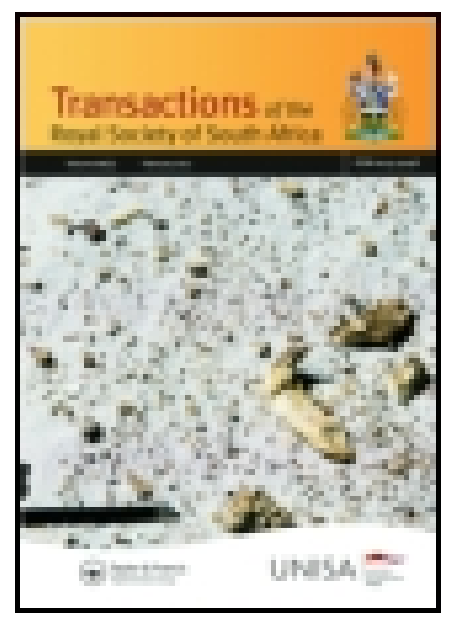

\title{
Transactions of the Royal Society of South Africa
}

Publication details, including instructions for authors and subscription information:

http:// www.tandfonline.com/loi/ ttrs20

\section{LUMINOSITY AND ITS ORIGIN IN A SOUTH AFRICAN EARTHWORM (CHILOTA SP.?)}

J. D. F. Gilchrist M.A., Ph.D., D. Sc.

Published online: 26 Mar 2010.

To cite this article: J . D. F. Gilchrist M.A., Ph.D., D. Sc. (1918) LUMINOSITY AND ITS ORIGIN IN A SOUTH AFRICAN EARTHWORM (CHILOTA SP. ?), Transactions of the Royal Society of South Africa, 7:1, 203-212, DOI: 10.1080/00359191809519562

To link to this article: http:// dx.doi.org/ 10.1080/00359191809519562

\section{PLEASE SCROLL DOWN FOR ARTICLE}

Taylor \& Francis makes every effort to ensure the accuracy of all the information (the "Content") contained in the publications on our platform. However, Taylor \& Francis, our agents, and our licensors make no representations or warranties whatsoever as to the accuracy, completeness, or suitability for any purpose of the Content. Any opinions and views expressed in this publication are the opinions and views of the authors, and are not the views of or endorsed by Taylor $\&$ Francis. The accuracy of the Content should not be relied upon and should be independently verified with primary sources of information. Taylor and Francis shall not be liable for any losses, actions, claims, proceedings, demands, costs, expenses, damages, and other liabilities whatsoever or howsoever caused arising directly or indirectly in connection with, in relation to or arising out of the use of the Content.

This article may be used for research, teaching, and private study purposes. Any substantial or systematic reproduction, redistribution, reselling, loan, sub-licensing, systematic supply, or distribution in any form to anyone is expressly forbidden. Terms $\&$ Conditions of access and use can be found at http://www.tandfonline.com/page/terms-and-conditions 


\title{
LUMINOSITY AND ITS ORIGIN IN A SOUTH AFRICAN EARTHWORM (CHILOTA SP.?).
}

By J. D. F. Gilchrist, M.A., Ph.D., D.Sc.

\author{
(With Plate XXIV.)
}

Cases of luminosity or phosphorescence in earthworms have from time to time been observed. From 1670 (Grimm) up to the present day there are records of such observations. Vejdovsky (1884) found the common earthworm Allolobophora foetida to give out an occasional phosphorescent light, from the glandular cells of the epidermis he believed; and Owiannikow (1864) observed Enchytraeus albidus, probably identical with Lumbricus noctilucus of Eversmann (1838), to show a light, which appeared, sometimes on the head region, sometimes on the tail, and, at other times, over the whole body. According to. Flaugergues (1771), the light occurs chiefly at the region of the clitellum, and disappears after copulation. Moquin Tandon and Panceri (1875) also believed that the clitellum is the source of the luminosity. Giard (1887), on the other hand, found small, luminous worms, which he calls Photodrilus, and indicates that the source of luminosity is in certain glands, which surround the alimentary tract, and open on the back of the animal to the exterior. In addition to the authors quoted, others, such as Dugès (1837), Moniez, Stein (1831), Matzdorff (1883), Haupt (1903), etc., also mention luminosity in earthworms (see references).

It does not appear, therefore, that there can be any doubt as to the occurrence of the phenomenon, though there is much diversity of statement as to the facts and the probable cause of the luminosity. In view of this uncertainty, the most recent view on the subject is that the luminosity is brought about secondarily, and is probably due to the presence of luminous bacteria or fungi in the body of the earthworm. Mangold (1910) suggests luminous bacteria or fungi, and he remarks that it is strange that a peculiarity of such a striking nature in an animal so common as the earthworm should be so little known. The latest reference is contained in Dahlgren's account of luminous animals (1916). While he finds many accurate and exhaustive accounts of luminosity or luminous organs in other animals, including the marine worms, he finds nothing definite to record in the case of earthworms, and is inclined to believe that the luminosity is due to the accidental presence 
of luminous fungi in the food of the animal. The presence of luminous bacteria or fungi seems a most probable explanation, and appears to be generally accepted, but, maybe, it is just because of this plausibility that the phenomenon has not been adequately investigated.

There does not appear to be any record of such an occurrence in S. Africa, and yet it does not seem to be uncommon, for several correspondents have assured me that luminous "worms" have been observed in up-country districts. In some of these cases it is possible that the common glow-worms or centipedes may have been mistaken for worms. More convincing evidence has been obtained, however, nearer Cape Town. Mr. MacManus has, he informs me, frequently seen earthworms on damp nights crawling up on the verandah of his house, near the foot of Signal Hill, leaving a trail of luminous substance; on a dark, wet night at Salt River, a patch of luminous material was observed, which was given out by an earthworm; a collector of material for the Zoological Department of the S. African College has frequently seen luminous worms at Maitland, and my friend, Dr. Purcell, informs me of an interesting case near Hermanus on the south coast. His attention was first attracted by observing the phosphorescence on a number of small toads in the grass after rain. Luminous fragments of earthworms were found on the spots occupied by the toads. Dr. Purcell was not sure that the toads had partly eaten the worms, but he attributed their luminosity to contact with the worms. The toads, on crawling away, left a luminous trail behind them; he also informs me of another instance, in which he observed luminous patches on a spider, found in the grounds of the South African Museum. These patches were readily brushed off, and were believed to have been caused by contact with some luminous animal, probably a worm.

That luminous earthworms are widely distributed in this country is rendered probable by an observation of Mr. E. J. O'Connor, who informs me that he has often seen them in damp weather at Limbe in the Shire highlands of Nyasaland.

The occasion for these inquiries was the finding of several examples of a species of earthworm (apparently a species of Chilota), which certainly did produce a very striking display of light. The first specimen found was on July 19th, 1917, after an exceptionally heavy rain. It was found at dusk on a footpath through the pine-woods on the slopes of Table Mountain. The light given off was conspicuous, and could not have been overlooked by the most casual observer. A few yards further on another specimen was observed. In the first case there were patches of a luminous substance a few inches from each other, as observed in the case mentioned by Giard. In the second case these were closer together, and within an area which could be covered by the palm of the hand. The general appearance was not unlike that shown in Fig. 1, which was obtained by placing a worm on a photographic plate in the dark. The irritation of the dry plate caus ed the animal 
to give out the luminous fluid, and, on development, the luminous patches appeared as shown.

That the occurrence is not a usual one in this locality is evident from the fact that this particular path had been traversed almost daily, at all seasons of the year, and in all weathers, without any sign of the presence of such worms.

These earthworms were apparently not in the normal condition, having probably been driven out of their burrows by the unusual wetness of the soil. An endeavour was therefore made to find them in their natural habitat, and in sufficient quantity to afford material for more careful examination. The spot where they were found was dug up to a considerable depth, but none were discovered. At other places various species of earthworms were readily found, but were not luminous. On continuing the search, however, a species was dug up, which gave out a distinct light on handling, and ultimately several spots were found, where the worm could be got in sufficient abundance.

\section{How the Light is Given Off.}

It was not at first observed from what part of the animal the light was produced. In the first example procured it was found on the head and tail regions, as well as on other parts of the body. Subsequent and repeated experiments, however, seemed to indicate clearly that it was given off only from the mouth and anus, except in those cases when there was some injury to the body. The luminosity proceeded from a discharge, which was sometimes of a viscid, mucus-like consistency, sometimes of a more fluid nature. This discharge was given out in various ways, but only after a certain amount of irritation. When first dug up the worm usually assumed a rigid attitude, and could be handled freely without exhibiting any movementperhaps a death-feigning device. Usually, however, after a time, it began to exhibit very lively movements, and, by a series of strong flexures of the body, to throw itself about, scattering masses of luminous substance in all directions (Fig. 1). If held firmly to prevent such movements the fluid could be seen to proceed from the mouth, and, to a less extent, from the anus. It usually flowed out somewhat suddenly and spread over the body, but, in several instances, it was ejected with considerable force to some distance. In many instances, when examined in the dark room, spots of light appeared unexpectedly in various places, usually on the clothes of the observer. The clear pear-shaped patch in Fig. 1 is apparently produced by such an ejected mass of luminous fluid.

The diversity of statement in other cases as to the region of the body on which the light appears may be due to the accidental contact of the body with the discharged mucus when the animal is captured, as was the case here. If, however, the animal is handled carefully, it may be washed in 
water, and even dried subsequently on blotting-paper without exciting any discharge. A worm treated in this way was placed between two photographic plates in a dark room. The adhesion of the dry surface of the film prevented any movement of the animal, and, at the same time, induced a discharge. The details of this could be watched through the plate. A light spot first appeared at the mouth, and slowly spread backward over the surface of the anterior segments of the animal. Similarly, but some time afterwards, a light spot appeared at the anus, spreading on to the surface of a few of the posterior segments. The earthworm was then removed, and on developing these light areas appeared as a blacking of the plate (Fig. 2). In another case the spreading of the fluid was allowed to go further, and the whole of the body of the worm ultimately became enveloped in the luminous substance. Here also the light was observed to appear first at the mouth and anus, and thereafter to spread over the body. To obtain further information as to the source of the luminosity, a worm was compressed between two plates, before the luminous fluid had time to spread along the body from the mouth and anus. The result is seen in Fig. 3, in which it will be noted that the luminous fluid has been foreibly ejected at the various parts where the body has been ruptured. In interpreting this result, it must be remembered that, after the compression, there was time for the fluid to spread to some extent between the closely applied plates elsewhere than at the place where the fluid was first ejected. It was at first supposed that the luminous substance had been ejected from the alimentary canal, but, as will be shown later, its actual seat is in the body carity.

\section{The Luminous F'luid.}

When first extruded the luminous fluid appeared of a whitish colour in daylight, and could not well be detected, except with careful observation under a lens. If shaded hy the hand, however, it could be seen to be of a greenish colour, and to be luminous. When examined under the microscope it was found to consist of a great number of cells, so densely packed together as to be in contact with each other. Occasionally a greater or less amount of a viscid mucus occurred along with these, but, though the cells were more or less entangled in this mucus, it apparently was not necessarily associated with them. There was also present in all cases a certain amount of clear, watery fluid.

The greater majority of the cells were of a large size, the largest being about $20 \mu$ in diameter. These were very heavily laden with inclusions, most of which were rounded, apparently of a fluid nature, and of a greenish colour. These were also of various sizes, the largest being about the size of the nucleus of the eell Scattered among these were small specks or granules, apparently of a more solid nature.

'I'he most of these cells showed no movement, but a slow movement could 
be detected in some, and, in a few, this was well marked. After a time all these cells became disintegrated, and, soon after the commencement of this process, the whole of the contents of the cell became scattered about in the surrounding clear fluid.

Other cells, fewer in number and smaller, were also found, circular in outline with a clear border and small inclusions in the centre, and appeared to be earlier stages in the formation of the large cells.

More numerous, and entirely devoid of inclusions, were numbers of much smaller cells, with relatively large nucleus and irregular outline. Some of these showed active movement, when observed in the fresh condition, either in a hanging drop or under a cover-glass.

In addition to these there were frequently observed gregarines of at least four different species. In several instances there were also present the typical pseudo-navicellae or spores of the gregarines, and these were often seen associated with groups of the smaller cells above referred to.

\section{Nature and Cause of the Luminosity.}

The amount of luminous fluid discharged varies very considerably, both according to the extent of the irritation and the condition of the animal, but the intensity of the luminosity appeared to be always in proportion to the quantity of the fluid. A quantity, about the size of a pin's head, when placed on a slide, maintained its luminosity for a few minutes only, but, when the discharge was abundant, as, for instance, when it covered au area the size of a sixpence or even overflowed the slide, it retained its luminosity for over an hour. When a small quantity was at once shaken up in about 20 c.c. of water, the water became faintly luminous, and retained its luminosity for over two hours. The intensity of the luminosity may be judged by the fact that moderately large print could be made out in the dark room when close to the light. When left on a fairly slow photographic plate (Ilford ordinary) for about half a minute, the blacking of the plate proceeded on development in a normal way for correct exposure.

The luminous fluid could be examined microscopically in a dark room hy the aid of its own light. This examination did not, however, at first prove so instructive as might have been expected, for the light given off presented the appearance of a uniform glow without any differentiation. This was due apparently to the fact that the light was produced during the process of the breaking up of the granular cells already mentioned, and the scattering of their contents. That these contents were still capable of giving out light after discharge was evident from the fact that light was produced after all the cells had been disintegrated, and that the luminous fluid, after being shaken up in water and passed through filter paper, was still luminous.

Though the fluid was repeatedly examined under the mieroscope with varying magnifications without any differentiation heing detected, on one 
occasion, after prolonged observation, and when the fluid was almost dried up, innumerable minute specks of bright light were plainly seen. These were well defined, each standing out distinctly on the dark background as a bright star-like glow. The glow of each particle did not, however, last for more than six to ten seconds, though some remained distinct for about thirty seconds. The light appeared first as a faint speek, and gradually reached its maximum as a steady glow, when it faded off rather suddenly. This appearance was not readily observed in this way, and often the light died down uniformly. Another method, however, by means of which the luminous particles could be readily distinguished was subsequently found, when it was accidentally discovered that the fluid so dried up could be again made luminescent by the application of water. If a quantity of water be put on the slide, it was noticed that, at the point where it came in contact with the dried substance, a distinct glow appeared, and this, when examined in the dark under the microscope, was seen to consist of numerous, discrete, luminous particles. As the water encroached on the dried substance, an area of bright luminous specks, like a starry sky, passed slowly over the field of vision, at the point of contact of the water and dried substance. Subsequently it was found that the luminosity could also be renewed simply by breathing gently on the dried slide, but in this case it was of very short duration. The experiment was then tried of drying the slide rapidly, by subjecting it to a temperature of about $60^{\circ} \mathrm{C}$., when the luminosity again reappeared on the application of moisture.

It was, of course, impossible to locate the exact position of these luminous particles with reference to the cells in the fluid, which were invisible in the darkness, but by turning on an artificial light after their position in the field of vision had been noted, it was observed that they were situated in the cells, but that all of the cells were not luminous, or at least did not give out light sufficiently strong to be seen through the lenses of a microscope. It was only on one occasion, however, that three such isolated cells were observed to have these luminous particles, and then they were apparently in the process of breaking down.

The luminous particles were found amongst the discharged granules of the cells in abundance.

The size of the luminous particles could not be accurately ascertained, but they were of about the same size as the small particles already mentioned as occurring in the cells, and there is good reason for believing that they were identical with them. Such solid particles are known to occur in the cells of the body cavity, and are believed to be the result of the transformation of the fluid spheres, which are purely excretory matter. Thus. Kükenthal and Joseph describe in Tubifex and Lumbricus the large brown masses in the chloragogen cells as being transformed into small solid and dark particles. In the present case, however, these particles appear to be of 
fatty nature, as they stain with osmic acid and Sudan III. But, though there seems now to be a general agreement that the chloragogen cells contain only excretory matter, the presence of fat has been detected in those of some Limicola, especially the family of the Enchytraeidae (Rosa, Freudweiler). Willem has found fat globules in the chlorogogen cells of Arenicola, and Ashworth in those of the Polychaete Halla.

If these particles be of the nature of fat, the luminescence is sufficiently explained, as being merely a process of oxidation, as it is known that some substances of this nature react in this way.* As further evidence that the luminosity is caused by oxidation, I may mention that a quantity of the fluid, left on a slide under a cover-glass for a few days, was observed to give out light on removal of the cover-glass and exposure to the air. In one case the fresh material had been observed under a cover-glass ringed with vaseline to exclude air ; after examination the slide was put aside, and, about a month afterwards, on removing the cover-glass to clean the slide, the fluid was observed to be distinctly luminous, both on slide and cover-glass. Another slide of the same kind was kept about two months, but gave out no light when the cover-glass was removed. It would thus appear that a slow process of oxidation takes place, during which no visible light is given off. Further evidence of this is that if the fluid be dried on the slide, and left for a few hours exposed to the air, it does not become luminous on the application of water or moisture. It may be noted also that if the luminous fluid be rubbed on a cloth or other substance the luminosity is increased, but dies down quickly.

The test for luciferin and luciferase was applied, but these substances are apparently not present.

\section{Origin of the Luminous Cells.}

The cells, laden with inclusions of various sizes, might be the cells given off from some tissue of the earthworm itself, or cells of some parasitic protozoon undergoing rapid multiplication. They resemble most the free cells found in the body cavity of the earthworm, either chloragogen cells, or amoebocytes, laden with excretory matter; but such cells are not known to find access to the digestive tract, though it may be noted that at first they were believed to form digestive ferments (D'Udekem) - a supposition which was abandoned when it was recognised that it was "impossible that the contents of the chloragogen cells could be poured into the lumen of the alimentary tract" (Burian).

This being so, it was apparently impossible that the cells discharged from the mouth could be cells from the body cavity. It was therefore conjectured that they were some stage in the life-history of a protozoon para-

* E. Newton Harvey, "Studies in Biolumiscence," "American Journal of Physiology, vol, xli, No. 4, 1916. 
site, and the presence in several cases of numerous "pseudonavicellae" seemed to indicate that this parasite was a gregarine.

It was found, however, on making sections, that the cells undoubtedly proceeded from the body cavity by a comparatively large aperture on the floor of the buccal cavity; posteriorly also, within or at the edge of the anus, a small aperture was found on the dorsal aspect leading into the body cavity. There could be little doubt on this point, for sections were made of a worm which had just discharged the luminous fluid from the mouth, and in the sections the remains of this fluid in the mouth cavity could be clearly followed through the aperture to the body cavity. The structure and nature of these openings will doubtless prove of interest, but we are not concerned with them here further than that they throw light on the origin of the luminous cells.

It was expected that the coelomic fluid and its contained cells would be ejected by the dorsal pores, as was found to be the case in a species of Lumbricus obtained from the same locality, when placed in a preservative. This, however, was not the case; indeed, dorsal pores seem to very inconspicuous or absent in this species of Chiloti, as none were seen.

The luminous cells therefore originate from the body cavity, and are apparently either free chloragogen cells or amoebocytes, or, maybe, a mixture of these.

\section{Biological Significance of the Luminosity.}

So striking a feature as the production of light by an animal naturally suggests the likelihood of a specific purpose for which the light is produced. 'There is usually, however, a considerable difficulty in assigning to it any definite function with certainty, even in those animals with distinct and somewhat complicated organs for the production of light. Thus, for instance, while it has been maintained with a good deal of reason that the light produced by the fire-fly, certain fishes and crustacea are secondary sexual characters, this has been disputed. Certain luminous organs are apparently for the attraction of the prey of the animal, for scaring off or misleading enemies; but while the complexity and apparent purposefulness of the organs undoubtedly point to a definite function, the proof of this, founded on facts, is markedly wanting. If this be the case in the higher animals it is much more so in the lower. Luminous protozoa such as. Noctiluca, so well known, luminous bacteria, equally well known, have no obvious " use" for their luminosity. There is no difficulty in suggesting a plausible use for the luminosity in the earthworm. Thus, when this luminous worm was first found crawling about on the surface of the ground in the semidarkness, the patches of luminous mucus, while so readily attracting •attention, apparently served the purpose of drawing off attack from the worm itself, as it actually did in the observed cases - a common enough expedient in some animals, which sacrifice a conspicuous organ by throwing it off from 
the body. The utility of luminosity is apparently still more obvious in the underground life of the animal. Thus it is guarded in its burrow from attacks both in front and in the rear, and any predaceous insect, centipede, or other enemy, on attacking the worm at either end, would be deluged in a blinding mass of luminous fluid, which, in the darkness of underground life, would be sufficiently alarming to cause a hasty retreat.

The behaviour of the worm also seems to indicate a defensive organ of this nature, for it most readily and in every case gives off the luminous fluid if the head or tail is slightly touched by a sharp pin or needle. The fluid was, as stated, sometimes ejected to a considerable distance, and recalled the similar, but much more definite, ejection of a mucous substance by Peripatus.

The facts narrated suggest several other promising subjects of investigation for workers in S. Africa. Other species of earthworm in S. Africa would probably be worth investigating from this point of view. For instance, in digging for worms in a garden a species was found, but only one example, which gave out an abundant discharge from the mouth, consisting mainly of cells such as described but showing no luminosity. Again the chemical nature of the luminosity is a promising line of research, as the material is so readily got and manipulated; the exact nature and origin of the cells, which occur in such numbers, is a subject worth investigating; and, lastly, the structure, origin, and possible homology of the communications between the coelom and digestive tract.

I have to express my indebtedness for assistance in literature to my colleagues, Prof. Jolly and Mr. Van der Lingen; to Dr. Robertson, Government Bacteriologist, for examination of the luminous fluid for the presence of bacteria; and to Dr. Battaerd for confirmation of the fatty nature of the small granular inclusions of the cells.

\section{Suminary.}

(1) A few examples of a species of luminous earthworm were found on the surface after heavy rains, and subsequently in quantity by digging in the ground.

(2) The luminosity proceeds from a fluid discharged from the mouth, and, to a less extent, from the anus.

(3) The luminous fluid consists mostly of single cells heavily laden with inclusions of different kinds.

(4) The luminosity is given out by the inclusions of small size, and these seem to be of a substance allied to fat, by the oxidation of which the light is produced.

(5) The cells arise in the body cavity, and are discharged into the anterior and posterior ends of the alimentary tract by definite communications between coelom and alimentary tract. 


\section{RefFerences and Bibliography.}

1670. Grimm.-Quoted by Friend, 1893.

1771. Fuavanrgues.-_ "Lettre sur le phosphorisme de vers de terre," ‘Journ. de Phys.,' t. $16(1771)$, p. 311.

1792. Brugière. - "Sur la qualitê phosphorique du ver de terre dans certain circonstances," 'Journ. d'Hist. nat.,' t. 2, p. 267.

1831. Strin, F. V.-" Ueber einen nenen das leuchten der ostsee bedingenden lebenden Körper," 'Paggendorff's Ann. d. Phys. u. Chem., Bd. 33, p. 410 (1831).

1837. DuGk̀s, ANT._-“Lumbricus phosphoreus," 'Ann. Sc. Nat.,' ser. 2, vol. 8, pp. 17, 24.

1838. Eversmann.-_ “Lumbricus noctilucus," 'Utchen. Zapiski. Kazan. Univ.,' 1838, pp. 156-157 (Russian).

1843. Altman showed at Cork meeting of British Association luminous earthworm from bogs of South of Ireland, 'Report of British Association,' 1843, p. 76.

1853. Cox showed luminous earthworm at a meeting of Lit. and Phil. Soc., Liverpool. 'Proc.,' No. viii, p. 57.

1864. Ofsiannikow, Pн.- "Ueber das Leuchten der Larven von Lampyris noctiluca," 'Bull. acad. imp. sc. St. Petersbourg,' t. 7, p. 55.

1872. SecCHI.-'Nouv. observ. Ann. Sc. Nat.,' ser. 5, vol. xvi, 1872.

1873. Cонn._-_Leuchtende Regenwurmer," 'Zeitschrift für Wiss. Zool.,' vol. xxiii, pp. $459-461$.

1875. Panceri, P.—" La luce e gli organi luminosi annalidi," "Atti. della R. Accad. d. Sc. fis. e nat.,' vol. 7, No. 1.

1884. VeJdovsky.- 'System u. Morphologie der Oligochaeten. Prag.'

1887. GIARD.-“Photodrilus phosphoreus,” C. R. ac. sc.,' vol. 105, p. 872.

— HARKER.- “On a Luminous Oligochaete (Enchytraeus)," 'Rep. Brit. Ass.,' 1887, p. 767.

- A trkinson, G. F.- "A Remarkable Case of Phosphorescence in an Earthworm," 'American Naturalist,' vol. xxi, pp. 773-774.

1891. Barrors, Th.-" Sur le presence de Lumbricus (Photodrilus) phosphoreus, Dugès, à Groffliers (Pas de Calais),” 'Rev. biol. Nord France,' t. 3, No. 3. pp. 117-119.

1893. MatzdorfF.—“In Berlin aufgefundeme leuchtende Regenwürmer," "Sitzb. d. Ges. Naturf. Freunde,' 1893, pp. 19.23 (gives synopsis of previous records).

FrIEND, H._"Luminous Earthworms," "Nature,' vol. 47, 1893, p. 462.

1897. __ "Earthworm Studies: Phosphorescence and Luminosity," 'The Zoologist,' July 15th, 1897, vol. i, No. 7, p. 304.

1903. HaUPr, H.-“"Leuchtende Organismen," "Naturwiss. Wochenschr.,' 1903, p. 65.

1910. Mangold.- "Die Produktion von Licht," "Handbuch der vergleichenden Physiologie.'

1914. FrieND, H.-“Annelid Luminosity in Nottingham," “Tr. Nat. Soc.,' 1912-13 (1914).

1916. Dahlaken, U.-“ The Production of Light by Animals," 'Journ. Franklin Inst.,' vol. 181, No. 5 .

EXPLANATION OF PLATE XXIV.

FIG.

1. Light produced from earthworm placed on photographic plate.

2. Light produced from earthworm held stationary between two photographic plates.

3. Light produced from earthworm compressed between two photographic plates. 


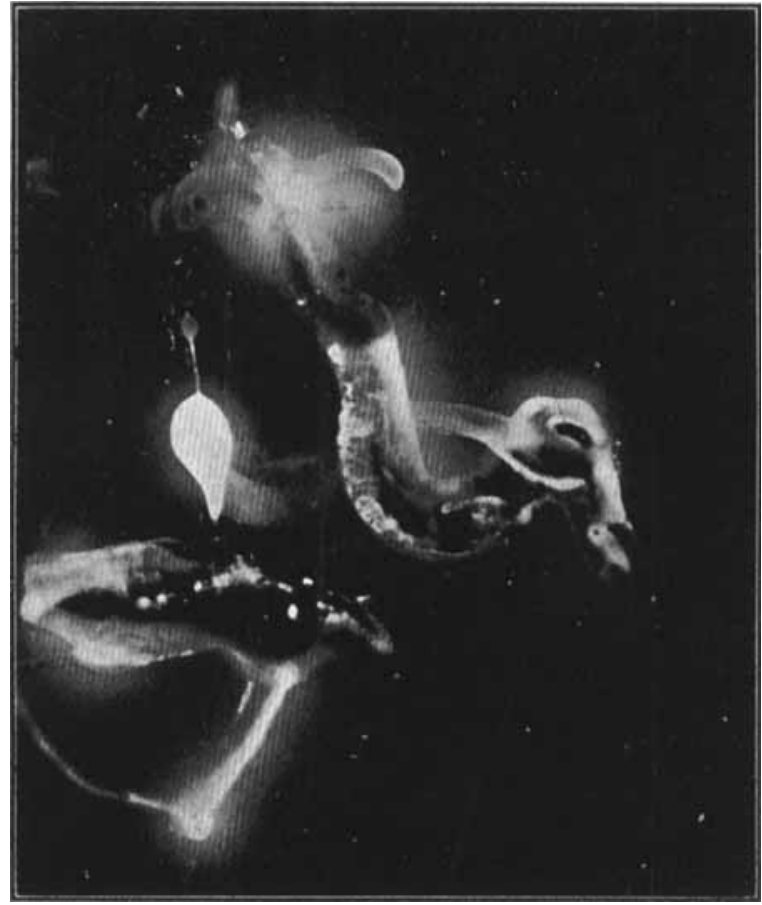

FIG. 1.

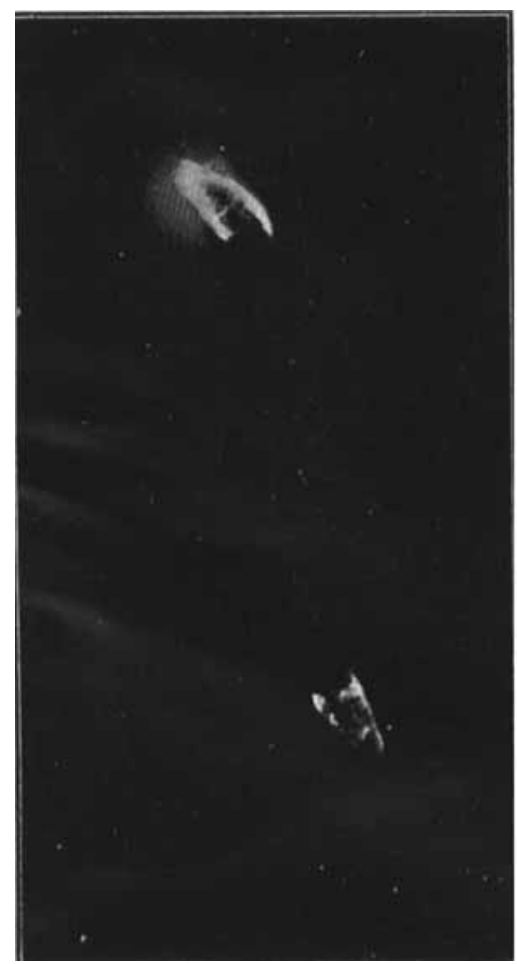

Fig. 2.

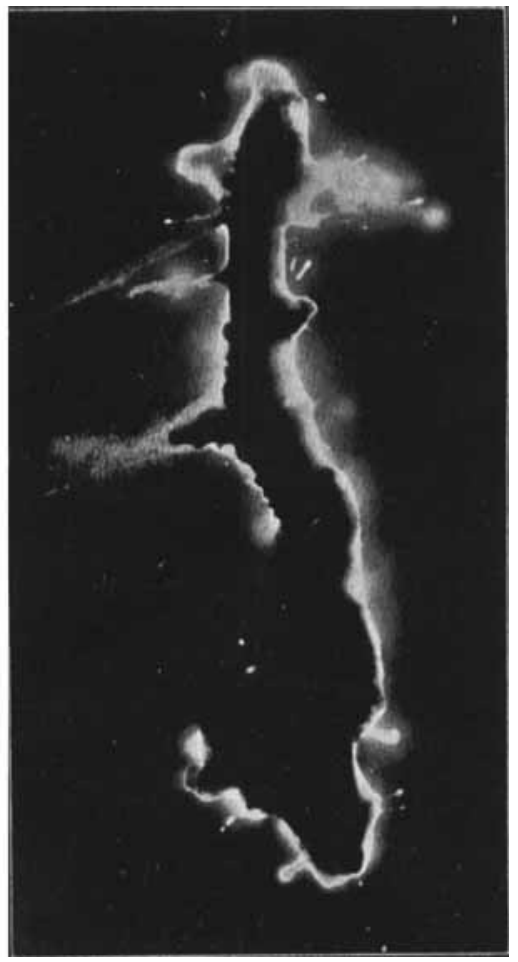

FIG. 3.

Adlard \& Son \& Wet Nerman, Ltt 